\title{
PENGEMBANGAN PERANGKAT PEMBELAJARAN PADA MATERI POKOK KALKULUS SMA KELAS XI SEMESTER 2
}

\author{
Sumarno ${ }^{1)}$, Dhoriva Urwatul Wustqa ${ }^{2)}$ \\ SMA Negeri 1 Kasihan Bantul ${ }^{1)}$, Universitas Negeri Yogyakarta ${ }^{2)}$ \\ sumarno.math@yahoo.com ${ }^{1)}$,dhoriva@yahoo.com ${ }^{2)}$
}

\begin{abstract}
Abstrak
Penelitian ini bertujuan untuk menghasilkan perangkat pembelajaran kalkulus SMA kelas XI semester 2 dengan metode pembelajaran kooperatif tipe STAD dan TAI yang layak digunakan dalam proses pembelajaran, serta mendeskripsikan kelayakan perangkat pembelajaran yang dikembangkan tersebut, berdasarkan pada kriteria dari Nieveen, yaitu valid, praktis, dan efektif. Penelitian ini adalah penelitian pengembangan yang menggunakan model pengembangan 4-D yang dikembangkan oleh Thiagarajan, Semmel dan Semmel. Tahap-tahap yang dilakukan meliputi tahap pendefinisian, tahap perancangan dan tahap pengembangan. Pengembangan perangkat dimulai dari tahap analisis awalakhir, analisis siswa, analisis materi, analisis tugas, spesifikasi tujuan pembelajaran, pemilihan media, pemilihan format, desain produk. Uji coba dilaksanakan dalam tiga tahap, yaitu uji coba/validasi ahli dan praktisi, uji coba terbatas, dan uji coba lapangan. Penelitian ini menghasilkan perangkat pembelajaran kalkulus SMA yang berkualitas dan layak digunakan dalam proses pembelajaran. Masing-masing komponen perangkat pembelajaran tersebut memenuhi kriteria sangat valid, praktis dan efektif.
\end{abstract}

Kata kunci: pengembangan, perangkat pembelajaran, pembelajaran kooperatif

\section{DEVELOPING CALCULUS INSTRUCTIONAL PACKAGE FOR SENIOR HIGH SCHOOL IN GRADE XI, SEMESTER 2}

\begin{abstract}
This research is aimed to produce a calculus instructional package which is suitable for grade XI Senior High School students in semester 2 using cooperative learning of STAD and TAI types and describe the quality of the product based on Niveen criteria, including validity, practicality and effectiveness. This research is a developmental research. The model of the instructional package in this research was adapted from 4-D development model from Thiagarajan, Semmel and Semmel. The steps cover define, design, and develop. The Instructional package starts from front-end analysis, learner analysis, concept analysis, task analysis, specification of objectives, media selection, format selection, initial design. The try out was done in three stages, i.e. try out/expert judgment, small group try out, and field try out. The research produced calculus instructional package for Senior High School which are qualified and suitable in the teaching learning process. Each instructional package component is valid, practical, and effective.
\end{abstract}

Keywords: developing, instructional design, cooperative learning 


\section{PENDAHULUAN}

Pembelajaran matematika hendaknya memberikan kesempatan yang luas kepada siswa untuk terlibat secara aktif sehingga konsep materi yang dipelajari benar-benar tertanam dan di kuasai dengan baik. Tujuan pembelajaran matematika (Depdiknas, 2006) adalah agar siswa memahami konsep matematika, menjelaskan keterkaitan antar konsep dan mengaplikasikan konsep atau algoritma, secara luwes, akurat, efisien, dan tepat dalam pemecahan masalah. Ketercapaian tujuan tersebut sangat bergantung pada proses pembelajaran di kelas yang dilaksanakan guru sebagai agen pembelajaran dengan kompetensi yang mendukungnya, yaitu kompetensi pedagogik dan profesional.

Sebagai bagian yang penting dalam keberhasilan pendidikan, kompetensi pedagogik dan profesional guru merupakan dua kompetensi yang perlu mendapat perhatian lebih dibanding kompetensi lainnya. Hal ini dikarenakan bahwa, guru pada satuan pendidikan jenjang Sekolah Menengah Atas (SMA) yang memiliki kompetensi pedagogik maupun kompetensi profesional, dituntut untuk mengembangkan perangkat pembelajaran secara memadai agar pembelajaran sesuai dengan tujuan yang diharapkan.

Dalam praktiknya, dari hasil observasi dan wawancara terhadap 12 guru matematika SMA di Kabupaten Bantul diperoleh informasi bahwa hanya dua guru yang telah mengembangkan perangkat pembelajaran secara mandiri, sedangkan sepuluh guru lainnya menggunakan perangkat hasil download dari internet, copy file KD sebelumnya atau mengopi dari teman kemudian disesuaikan identitasnya. Apabila ditinjau dari komponen-komponen perangkat pembelajaran, semua guru tersebut telah memenuhi komponen-komponen minimal yang disyaratkan. Akan tetapi apabila ditinjau dari indikator pembelajaran dalam RPP, tidak semua guru merumuskan indikator dengan cara menurunkan Standar Kompetensi (SK) dan Kompetensi Dasar (KD). Sebanyak tujuh guru hanya mengikuti contoh hasil download di internet, copy file dari teman dan melihat buku pegangan. Hal ini bertentangan dengan yang tertuang dalam Permendiknas Nomor 41 Tahun 2007 tentang Standar Proses, bahwa "setiap guru pada satuan pendidikan berkewajiban menyusun RPP secara lengkap dan sistematis" (BSNP, 2007, p.2).

Ditinjau dari metode pembelajaran yang digunakan, kebanyakan guru menggunakan me- tode konvensional yaitu metode ceramah dan tanya jawab. Metode ini banyak digunakan guru karena mudah dilaksanakan, tetapi dalam metode ini peran guru sangat dominan sehingga pembelajarannya terkesan berpusat pada guru (teacher oriented). Guru menyampaikan materi pelajaran dengan menggunakan metode ceramah atau tanya jawab, sementara siswa mencatatnya pada buku catatan. Pada hal, pengajaran bukanlah semata-mata sebagai proses penyampaian fakta-fakta kepada siswa, akan tetapi siswa diberikan keleluasaan secara mandiri atau kelompok untuk menemukan fakta-fakta tersebut.

Sebagian besar guru juga belum mengembangkan Lembar Kegiatan Siswa (LKS) dan instrumen penilaian yang merupakan pendukung silabus dan RPP sebagai bagian dari perangkat pembelajarannya. Hal ini diperkuat oleh hasil angket yang diberikan kepada 12 guru matematika di Kabupaten Bantul. Dari 12 orang guru tersebut, 4 orang $(33,33 \%)$ tidak mengembangkan LKS sendiri, 6 orang $(50 \%)$ tidak menggunakan LKS, dan 2 orang $(16,67 \%)$ mengembangkan LKS sendiri. Untuk instrumen penilaian, 5 dari 12 guru $(41,67 \%)$ memperhatikan indikator yang ada pada SK dan KD dalam pembuatan instrumen penilaian, dan 7 orang $(58,33 \%)$ guru melihat dari materi yang telah diajarkan dan mengambil dari soal-soal yang sudah ada. Hal ini bertentangan dengan yang tertuang dalam Permendiknas Nomor 41 Tahun 2007 (BNSP, 2007, p.11), bahwa penilaian hasil belajar disesuaikan dengan indikator pencapaian kompetensi dan mengacu pada standar penilaian.

Silabus dan RPP yang digunakan guru Matematika Kabupaten Bantul sampai saat ini masih belum sesuai dengan Permendiknas Nomor 41 Tahun 2007 Tentang Standar Proses. Bagian RPP yang digunakan guru yang belum sesuai dengan peraturan tersebut adalah perumusan indikator pencapaian kompetensi dan tujuan pembelajaran. Dalam merumuskan indikator tidak dengan cara menurunkan Standar Kompetensi (SK) dan Kompetensi Dasar (KD). Tujuan pembelajaran yang dirumuskan hanya menggambarkan hasil, sedangkan proses yang menuju pencapaian hasil itu belum tampak. Hal lain yang belum sesuai dengan peraturan adalah uraian tentang materi ajar.

Materi ajar dalam RPP tersebut juga hanya dituliskan dengan materi pokok saja. Sedangkan dalam Permendiknas Tentang Standar Proses menyatakan bahwa "materi ajar memuat fakta, konsep, prinsip, dan prosedur yang 
relevan, dan ditulis dalam bentuk butir-butir sesuai dengan rumusan indikator pencapaian kompetensi" (BSNP, 2007, p.3). Kenyataan tersebut menunjukkan bahwa perangkat pembelajaran yang dibuat oleh sebagian besar guru matematika di Kabupaten Bantul belum sesuai dengan prinsip-prinsip penyusunan perangkat pembelajaran, sehingga diperlukan pengembangan perangkat pembelajaran yang sesuai dengan prisipprinsip penyusunan perangkat pembelajaran.

Materi pokok yang dipilih yaitu materi kalkulus SMA kelas XI semester 2. Hal ini berdasarkan hasil pengamatan di lapangan dan wawancara dengan teman sejawat di SMA Negeri 1 Kasihan, diperoleh informasi bahwa materi kalkulus kelas XI merupakan materi yang sulit untuk dipahami oleh siswa. Berdasarkan data hasil ulangan harian untuk materi kalkulus kelas XI, hasilnya memang masih banyak yang nilainya di bawah KKM. Hal ini diperkuat juga bahwa hasil ujian nasional untuk empat tahun terakhir materi turunan daya serapnya masih rendah.

Daya serap untuk standar kompetensi menggunakan konsep limit fungsi pada Ujian Nasional empat tahun terakhir siswa SMA N 1 Kasihan rata-ratanya 79,27 yang berarti sudah di atas KKM sekolah yang ditetapkan yaitu 75 . Sedangkan daya serap untuk standar kompetensi menggunakan turunan fungsi dalam pemecahan masalah rata-ratanya 52,01 yang masih jauh di bawah KKM sekolah. Daya serap untuk standar kompetensi menggunakan turunan fungsi dalam pemecahan masalah juga belum pernah sekalipun hasilnya melebihi KKM sekolah, bahkan ada kecenderungan hasilnya menurun dan tahun pelajaran 2011/2012 merupakan hasil yang paling rendah yaitu $32,41 \%$.

Matematika sulit bahkan menjadi fobia, lebih disebabkan pola pengajaran konvensional yang proses belajar-mengajarnya lebih menekankan pada ceramah guru, mengerjakan soal, hafalan dan kecepatan berhitung sehingga siswa kurang membuka wawasan pengetahuan, dapat menyebabkan siswa menjadi pasif sehingga siswa kurang paham dengan apa yang dipelajarinya yang dalam hal ini kurang memiliki pemahaman terhadap konsep yang diajarkan.

Untuk meningkatkan pemahaman terhadap konsep yang diajarkan diperlukan peran aktif siswa dalam pembelajaran. Oleh karena itu, perubahan pola pengajaran yang konvensional (teacher centered) menjadi pembelajaran yang berpusat pada siswa (student centered) sangat penting, karena proses pembelajaran harus memberikan ruang lebih banyak kepada siswa untuk membangun pengetahuan baru dan guru tidak hanya sekedar melakukan transfer pengetahuan kepada siswanya.

Belajar membutuhkan peran aktif siswa, yaitu dalam mengkonstruksi dan mengembangkan sumber belajar. Hal ini sebagaimana pendapat Steinbring (2005, p.35) bahwa "learning is seen as an active process of construction and development, which, through interaction, is the basis for the emergence of new knowledge". Sehingga peran siswa dalam proses belajar bukanlah sebagai suatu objek belajar, melainkan sebagai subjek belajar. Proses aktif siswa sebagai subjek belajar dapat dilakukan dengan interaksi, dan ini merupakan dasar atas munculnya pengetahuan baru.

Lingkungan merupakan tempat siswa untuk melakukan interaksi dalam pembelajaran. Sehingga dengan pentingnya lingkungan sebagai tempat dan sarana bagi siswa memperoleh pengetahuan baru, maka Suherman (2003, p.7) mendefinisikan pembelajaran yaitu sebagai upaya penataan lingkungan yang memberi nuansa agar program belajar tumbuh dan berkembang secara optimal. Penataan lingkungan dan perencanaan sebagai upaya membelajarkan siswa tersebut tidak terlepas dari peran serta guru. Fungsi guru dalam pembelajaran yaitu sebagai fasilitator dan mediator bagi siswa untuk memperoleh pengetahuan baru. Sebagaimana pendapat McLaughlin \& Talbert (Anderson, 2001, p.191) bahwa "in this view of teaching and learning, teachers' central responsibility is to create worthwhile activities and select materials that engage students' intellect and stimulate them to move beyond acquisition of facts to sense making in a subject area".

Pembelajaran matematika sekolah adalah proses penyampaian materi matematika yang dilakukan oleh guru melalui perencanaan, pelaksanaan, dan penilaian secara berkesinambungan untuk memfasilitasi peserta didik dalam membangun pengetahuan baru berdasarkan pengetahuan yang sudah diperoleh sebelumnya menggunakan strategi tertentu dengan memperhatikan karakteristik matematika sekolah dan tingkat perkembangan mental siswa.

Pembelajaran matematika sekolah harus memperhatikan penyajiannya, artinya penyajian matematika sekolah tidak secara langsung berupa butir-butir matematika. Metode pembelajaran yang digunakan harus disesuaikan dengan tingkat perkembangan intelektual siswa. Pembelajaran matematika akan bermakna apabila 
orientasi pembelajaran adalah pada siswa, bukan pada guru. Jadi siswa sebagai subjek belajar yang aktif untuk memperoleh pengetahuan baru tentang matematika. Sebagaimana pendapat Kennedy, et al. (2008, p.55) bahwa, "mathematical meaning is constructed by the learner rather than imparted by the teacher". Matematika yang bermakna adalah matematika yang terbentuk dari siswa bukan diberikan oleh guru.

Di dalam pembelajaran terjadi interaksi baik antar siswa, guru dengan siswa, maupun siswa dengan lingkungan sekitar. Adanya interaksi ini maka diperlukan suatu aturan sehingga proses pelaksanaan berjalan sesuai dengan yang diharapkan. Titik penting dari aturan yang mengatur interaksi tersebut adalah silabus. Hal ini sebagaimana pendapat O'Brien, et al. (2008, p.11), yaitu bahwa "syllabus is an important point of interaction between you and your students in and out of class". Silabus adalah titik penting dari interaksi antara guru dengan siswa baik di dalam maupun di luar kelas.

Silabus perlu disusun dengan baik agar hasil pembelajaran sesuai dengan keluaran yang diharapkan. Hal ini sebagaimana pendapat Prescott (2011, p.166), "syllabus is organized so that each learning outcome has a working mathematically outcome". Silabus diorganisasi sehingga setiap hasil belajar memiliki hasil matematis. Arti matematis disini adalah hasil pembelajaran dapat diperhitungkan dengan kompetensi-kompetensi yang harus dikuasai oleh siswa.

Di samping silabus, guru harus menyiapkan rencana pelaksanaan pembelajaran sebagai bagian utama dari kesuksesan dalam proses pembelajaran. Partin (2009, p.134) menyatakan, bahwa "A lesson plan is simply a sequential guide to how you will accomplish your instructional objectives or goals". Sebuah rencana pelaksanaan pembelajaran adalah sebuah panduan berurutan sehingga guru dapat mencapai tujuan pembelajaran. Menurut Harjanto (2003, pp.17-19) bahwa perencanaan akan mempermudah dalam menentukan target ketercapaian sebelum pelaksanaan dilakukan, menentukan langkah-langkah yang harus dijalankan selama pelaksanaan, dan mempermudah dalam evaluasi setelah proses pelaksanaan.

Sebelum melakukan pengembangan RPP, guru harus memperhatikan beberapa masukan yang terkait dengan pembelajaran. Masukan utama dalam penyusunan RPP menurut Borich (2000, p.113), yaitu "knowledge of goal and objectives, knowledge of learner character- istics, knowledge of subject matter, knowledge of teaching methods". Masukan yang harus diperhatikan dalam penyusunan RPP yaitu pengetahuan tentang tujuan pembelajaran, pengetahuan tentang karakteristik siswa, pengetahuan tentang materi pelajaran, dan pengetahuan tentang metode pembelajaran. Selanjutnya dalam Depdiknas (2008e, p.13) tentang langkah-langkah pengembangan RPP digambarkan sebagai berikut:

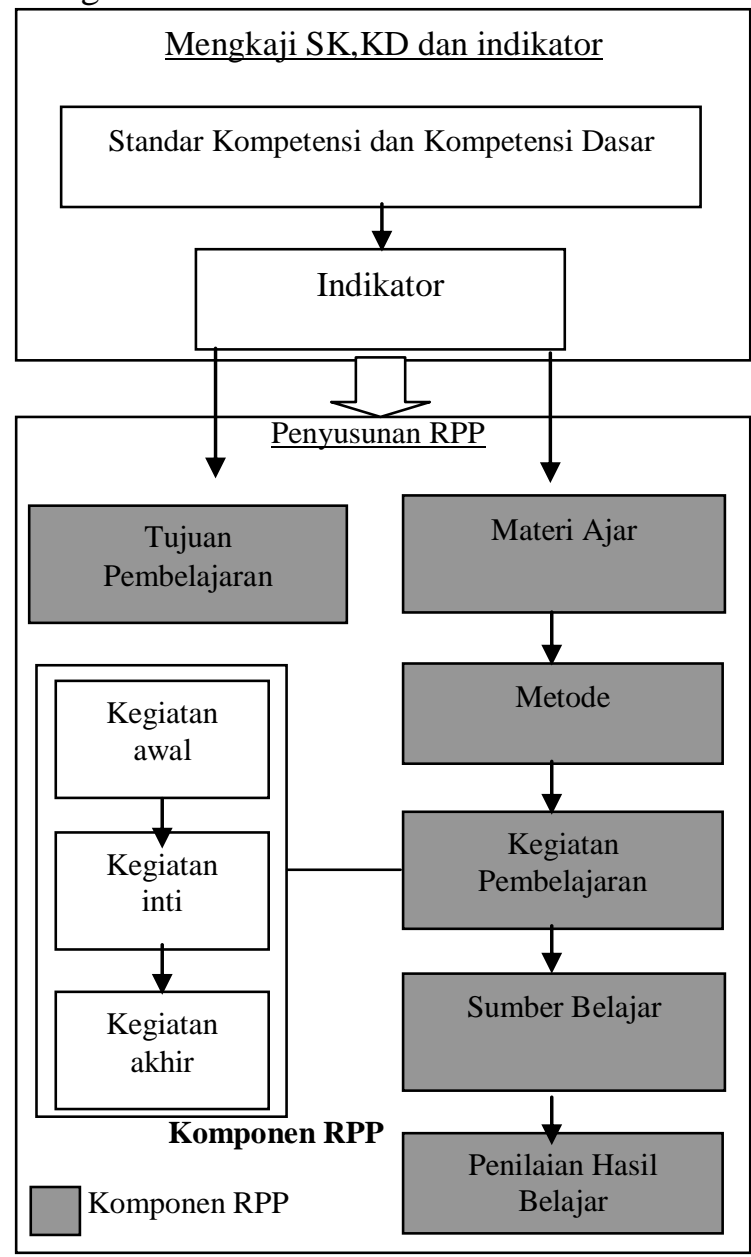

Dalam panduan tersebut secara khusus dinyatakan bahwa untuk memudahkan guru dalam melaksanakan pembelajaran dan memudahkan siswa untuk belajar secara mandiri, biasanya kegiatan inti dilengkapi dengan lembar kegiatan siswa (LKS), baik yang berjenis cetak atau non-cetak. Di samping itu dalam panduan tersebut juga dinyatakan bahwa sebuah rencana pelaksanaan pembelajaran (RPP) harus dilengkapi dengan perangkat penilaian yang dijabarkan atas teknik penilaian, bentuk instrumen, dan instrumen yang dipakai.

Paradigma baru dalam pembelajaran menuntut perubahan proses dari pembelajaran konvensional yang berpusat pada guru (teacher centered) menjadi pembelajaran yang berpusat 
pada siswa (student centerd). Salah satu metode pembelajaran yang berpusat kepada siswa dengan menekankan kerjasama antar kelompok untuk mendapatkan keberhasilan belajar baik secara individu maupun kelompok adalah dengan pembelajaran kooperatif. Pembelajaran kooperatif yang digunakan dalam penelitian ini adalah pembelajaran kooperatif tipe STAD dan kooperatif tipe TAI. STAD merupakan salah satu tipe pembelajaran kooperatif yang sederhana dan sangat baik bagi guru yang baru mengenal pembelajaran kooperatif. Menurut Trianto (2009, p.73) bahwa STAD masih dekat kaitannya dengan pembelajaran konvensional. Hal ini dikarenakan dalam salah satu fase STAD masih terdapat penyajian materi oleh guru. Yang membedakan dengan pembelajaran konvensional yaitu adanya pemberian penghargaan pada kelompok.

Adapun komponen utama dalam STAD menurut Slavin (1995, pp.71-73) yaitu: Class presentations (Presentasi kelas). Yaitu guru mempresentasikan materi pelajaran di depan kelas secara klasikal. Materi pelajaran berfokus pada materi yang akan digunakan sebagai bahan dalam pembelajaran dengan metode kooperatif tipe STAD. (2) Teams (Kelompok) .Kelompok terdiri dari 4-5 anggota kelompok. Kelompok ini ditentukan oleh guru dengan melihat prestasi, jenis kelamin, dan suku siswa. Kelompok dibuat seheterogen mungkin. Contoh penentuan anggota kelompok berdasarkan Slavin (1995, p.75) yaitu apabila jumlah siswa terdiri dari 22 siswa dan satu kelompok beranggotakan 4 siswa, maka akan terdapat 2 siswa yang belum mendapat kelompok. Dua siswa ini yaitu siswa yang ratarata prestasinya berada di tengah jika dibandingkan dengan siswa satu kelas. Selanjutnya mereka ditambahkan pada kelompok yang sudah terbentuk sehingga ada sebagian kelompok beranggotakan 4 orang, sedangkan kelompok yang lain beranggotakan 5 orang. Apabila dari hasil kelompok yang telah didapatkan masih terdapat kurang keheterogenannya, misal berkaitan dengan jenis kelamin, guru dapat mengubah konstruksi kelompok tersebut.

Quiz (Kuis). Setelah guru melakukan presentasi dan siswa berdiskusi dalam kelompoknya maka guru memberikan kuis untuk masingmasing siswa. Kuis dikerjakan secara individu oleh siswa. (4) Individual improvement scores (Peningkatan nilai individu). Dari hasil kuis yang diperoleh, setiap siswa berkontribusi terhadap keberhasilan pencapaian nilai kelompok. Berdasar nilai awal yang telah dimiliki masing- masing siswa, maka dapat ditentukan kenaikan atau penurunan nilai. Dari kenaikan atau penurunan nilai selanjutnya dilakukan penskoran titik perbaikan. Adapun dasar penskoran titik perbaikan menurut Slavin (1995, p.80) yaitu:

Tabel 1. Pedoman Penskoran Titik Perbaikan Individu

\begin{tabular}{cc}
\hline Nilai Kuis & $\begin{array}{c}\text { Titik } \\
\text { Perbaikan }\end{array}$ \\
\hline Lebih dari 10 poin di bawah skor awal & 5 \\
1-10 poin di bawah skor awal & 10 \\
0-10 poin di atas skor awal & 20 \\
Lebih dari 10 poin di atas skor awal & 30 \\
\hline
\end{tabular}

(5) Team recognition (Pengakuan tim). Tim atau kelompok bisa mendapat penghargaan jika rata-rata nilai melebihi kriteria tertentu. Dari hasil masing-masing perolehan skor titik perbaikan individu dalam satu kelompok selanjutnya dirata-rata sehingga didapatkan skor kelompok. Adapun predikat kelompok dari hasil ratarata yang didapatkan menurut Slavin (1995, p.80) yaitu:

Tabel 2. Predikat Kelompok

\begin{tabular}{cc}
\hline Rata-rata Kelompok & Kriteria \\
\hline 15 & Kelompok Baik \\
20 & Kelompok Hebat \\
25 & Kelompok Super \\
\hline
\end{tabular}

TAI merupakan salah satu tipe pembelajaran kooperatif yang dirancang untuk memperoleh manfaat yang sangat besar dari potensi sosialisasi yang terdapat dalam pembelajaran. Sebagaimana menurut Slavin (1995, p.98) bahwa "TAI math begas as an attempt to design a form of individualized instruction that would solve the problems that had made earlier individualized programs ineffective". Yang maknanya adalah matematika TAI diprakarsai sebagai usaha merancang sebuah bentuk pengajaran individual yang bisa menyelesaikan masalahmasalah yang membuat metode pengajaran individual menjadi tidak efektif. Bagaimanapun, individualisasi adalah bagian dari TAI yang membuatnya berbeda dari STAD dan TGT. Dalam matematika, kebanyakan konsep berdasar pada konsep sebelumnya. Jika konsep awal tidak dikuasai, dikemudian hari siswa akan kesulitan mempelajari lebih lanjut, seorang siswa yang tidak bisa pengurangan atau perkalian akan tidak mampu menguasai pembagian, seorang siswa yang tidak mampu memahami konsep pecahan akan tidak mampu memahami apa itu desimal, dan seterusnya. Dalam TAI, para siswa bekerja berdasarkan level mereka sendiri, jadi jika 
mereka kurang terampil dalam materi prasyarat mereka dapat membangun pondasi yang kuat sebelum melajutkan. Juga jika para siswa dapat maju lebih cepat, mereka tidak perlu menunggu yang lain yang belum selesai.

Adapun komponen-komponen dalam TAI menurut Slavin (1995, pp.102-104) yaitu: (1) Teams (Kelompok). Jumlah anggota kelompok dalam TAI sama dengan STAD, yaitu terdiri dari 4-5 anggota kelompok. Proses penentuan anggota kelompok dalam TAI juga sama dengan STAD yaitu berdasarkan nilai yang diperoleh siswa pada pertemuan sebelumnya atau pada tes awal. (2) Placement Test (Tes Penempatan). Tes ini berfungsi untuk penempatan dalam menentukan kelompok bagi seorang siswa. (3) Curriculum Materials (Materi-materi Kurikulum). Materi-materi dalam pembelajaran meliputi seluruh materi yang menjadi target pembelajaran. (4) Team Study (Belajar Kelompok). Setelah dilaksanakan placement test, pembelajaran dilanjutkan dengan presentasi dari guru di awal pembelajaran. Pembelajaran dilanjutkan dengan para siswa diberi kesempatan untuk memulai dalam unit matematika yang terdapat pada buku atau LKS panduan. Siswa mengerjakan unit-unit mereka dalam kelompok yang sudah terbentuk. (5) Team Score and Team Recognition (Skor Tim dan Rekognisi Tim). Skor kelompok ditentukan dengan jumlah latihan soal yang dapat diselesaikan oleh tiap anggota kelompok dan jumlah nilai kuis yang berhasil dikerjakan dengan benar. Kriteria yang tinggi ditetapkan bagi sebuah kelompok untuk menjadi kelompok super, kriteria sedang untuk menjadi kelompok sangat baik, kriteria minimum untuk menjadi kelompok baik.

Tabel 3. Perbedaan Cooperative Learning Tipe STAD dan Tipe TAI

\begin{tabular}{ccc}
\hline \multirow{2}{*}{ Tipologi } & \multicolumn{2}{c}{ Cooperative Learning } \\
\cline { 2 - 3 } & STAD & TAI \\
\hline Tujuan kelompok & Ya & Ya \\
Tanggung jawab individual & Ya & Ya \\
Kesempatan sukses yang & Ya & Ya \\
sama & & \\
Kompetisi tim & $\begin{array}{c}\text { Kadang- } \\
\text { kadang }\end{array}$ & Tidak \\
& Tidak & Tidak \\
Spesialisasi tugas & Tidak & Ya \\
Adaptasi masing-masing & & \\
individu & & \\
\hline
\end{tabular}

Perangkat pembelajaran merupakan komponen yang sangat penting dalam proses pembelajaran di kelas. Perangkat pembelajaran dapat digunakan sebagai pedoman guru dalam melak- sanakan proses pembelajaran di kelas sehingga proses pembelajaran bisa berlangsung lebih terarah menuju kompetensi yang akan dituju. Perancangan dan penggunaan perangkat pembelajaran yang baik diduga kuat dapat lebih meningkatkan hasil belajar siswa.

Oleh karena itu, penulis akan mengembangkan perangkat pembelajaran matematika pada materi pokok kalkulus SMA kelas XI menggunakan metode pembelajaran kooperatif tipe STAD dan TAI yang baik dan layak untuk digunakan, yaitu memenuhi kriteria valid, praktis dan efektif .

\section{METODE}

Jenis penelitian ini adalah penelitian pengembangan. Penelitian ini difokuskan pada pengembangan produk berupa silabus dan RPP serta kelengkapan komponen-komponenya. Produk yang dikembangkan yaitu silabus, rencana pelaksanaan pembelajaran (RPP), lembar kegiatan siswa (LKS), dan tes hasil belajar (THB). Model pengembangan perangkat pembelajaran yang digunakan dalam penelitian ini adalah model pengembangan pembelajaran $4 \mathrm{D}$, karena langkah-langkah yang terdapat pada model pengembangan ini sesuai dengan langkah-langkah yang diharapkan peneliti. Model pengembangan pembelajaran ini merupakan adopsi dari model pengembangan pembelajaran Thiagarajan, et al. Pengembangan pembelajaran model 4D menurut Thiagarajan et al (1974, p.5) meliputi Define, Design, Develop, dan Disseminate. Berdasarkan langkah-langkah pengembangan model 4D, tahapan dalam penelitian ini dibatasi sampai pada tahap Develop.

\section{Prosedur Pengembangan}

Tahap define, yaitu peneliti melakukan pengumpulan informasi-informasi berkaitan dengan produk yang dikembangkan. Pengumpulan informasi tersebut meliputi: (a) Analisis awal-akhir, yaitu peneliti melakukan observasi dan analisis terhadap kondisi atau keadaan guru di lapangan. Fokus dalam observasi ini adalah untuk mengetahui kelengkapan dan pelaksanaan perangkat pembelajaran matematika yang digunakan dalam pembelajaran; (b) Analisis siswa, yaitu peneliti melakukan observasi dan analisis terhadap kondisi siswa di lapangan. Fokus dalam observasi ini adalah untuk mengetahui kompetensi pembelajaran yang dirasakan sulit bagi siswa; (c) Analisis tugas, yaitu menganalisis kemampuan pelaksanaan pembelajaran yang dimiliki guru. Tinjauan dari analisis ini 
yaitu meliputi proses pelaksanaan dan metode pembelajaran yang digunakan guru; (d) Analisis konsep, yaitu menganalisis konsep dasar atau pedoman dalam melakukan pengembangan perangkat pembelajaran yang didasarkan pada Departemen Pendidikan Nasional, sehingga menghasilkan perangkat pembelajaran yang sesuai dengan Kurikulum Tingkat Satuan Pendidikan; (e) Spesifikasi tujuan instruksional, yaitu menggabungkan analisis-analisis yang telah dilakukan untuk menghasilkan solusi terhadap permasalahan yang dihadapi.

Tahap design yaitu, peneliti melakukan perencanaan dan perancangan awal dari perangkat pembelajaran. Langkah-langkah dalam tahapan ini meliputi: (a) pemilihan produk, dari hasil analisis yang telah dilakukan pada tahap define, maka produk yang dipilih dari pengembangan perangkat ini meliputi silabus, Rencana Pelaksanaan Pembelajaran (RPP), Lembar Kegiatan Siswa (LKS), dan Tes Hasil Belajar (THB); (b) pemilihan format, format yang digunakan terhadap perangkat pembelajaran yang dikembangkan tersebut yaitu mengikuti pedoman yang berlaku; (c) perancangan awal, perancangan awal dari pengembangan perangkat pembelajaran ini meliputi: (1) pembuatan silabus yang diturunkan dari Standar Kompetensi menggunakan konsep limit fungsi dan turunan fungsi dalam pemecahan masalah; (2) melakukan analisis indikator untuk menentukan metode pembelajaran yang digunakan; (3) pembuatan RPP dengan metode pembelajaran sesuai dengan analisis yang telah dilakukan; (4) pembuatan LKS untuk setiap RPP yang telah terbentuk; (5) pembuatan THB untuk mengukur kompetensi yang dikuasai siswa.

Tahap develop, dari tahapan kedua didapatkan produk yang berupa draf ke-1 yang selanjutnya dilakukan validasi, uji coba, dan revisi sehingga didapatkan produk yang valid, praktis, dan efektif. Adapun langkah-langkah dalam tahap ini yaitu meliputi: (a) Validasi yang bertujuan untuk mendapatkan masukan, saran perbaikan, dan sekaligus penilaian kevalidan produk sebelum dilakukan uji coba. Hasil dari validasi ini sebagai bahan revisi produk awal. Untuk tujuan tersebut digunakan instrumen lembar validasi produk (silabus, RPP, LKS, dan THB). Validator dalam penelitian ini yaitu 3 dosen Pendidikan Matematika FMIPA di Universitas Negeri Yogyakarta dan 3 guru mata pelajaran matematika SMA; (b) Uji coba terbatas melibatkan satu kelas yang beranggotakan 30 siswa dan seorang guru mitra. Uji coba terbatas bertujuan untuk mengetahui tentang pelaksanaan pembelajaran yang menggunakan produk tersebut. Kemudian data hasil uji coba terbatas dianalisis sebagai bahan revisi produk sebelum digunakan pada uji coba lapangan; (c) Uji coba lapangan dilakukan terhadap dua kelas yang beranggotakan 56 siswa. Data hasil uji coba lapangan ini dianalisa untuk mengetahui kualitas produk ditinjau dari kepraktisan dan keefektifannya.

Jenis data dalam penelitian ini meliputi data kuantitatif dan data kualitatif. Data-data ini bertujuan untuk memberi gambaran mengenai kualitas produk yang dikembangkan. Data kuantitatif diperoleh dari validasi ahli dan praktisi, lembar observasi, dan lembar penilaian yang berupa pernyataan tertutup, serta tes hasil belajar. Data kualitatif diperoleh dari validasi ahli dan praktisi, lembar observasi, dan lembar penilaian yang berupa pernyataan terbuka.

Analisis data dilakukan untuk mendapatkan bukti kevalidan, kepraktisan, dan keefektifan produk yang dikembangkan. Data yang diperoleh dari para ahli/praktisi dianalisis untuk menentukan kevalidan perangkat pembelajaran ditinjau secara teoritis dan konsistensi diantara komponen-komponen perangkat pembelajaran. Sedangkan data hasil uji coba di lapangan digunakan untuk menjawab kriteria kepraktisan dan keefektifan perangkat pembelajaran yang dikembangkan. Langkah-langkah yang digunakan untuk memberikan kriteria kualitas terhadap produk yang dikembangkan yaitu; (a) Data yang berupa skor penilaian ahli/praktisi , guru, dan siswa yang diperoleh dalam bentuk kategori terdiri dari lima pilihan tanggapan tentang kualitas produk perangkat pembelajaran yang dikembangkan, yaitu sangat baik (5), baik (4), cukup baik(3), kurang baik (2), dan tidak baik (1) dirubah menjadi data interval; (b) Skor yang diperoleh kemudian dikonversikan menjadi data kualitatif skala lima, dengan kriteria yang diadaptasi dari Direktorat Pembinaan SMA (2010, pp.59-60) pada Tabel 5 sebagai berikut.

Tabel 4. Kriteria Penilaian Skala Likert

\begin{tabular}{cc}
\hline Interval & Kriteria \\
\hline$M_{i}+1,8 S D i<\bar{M}$ & Sangat baik \\
$M_{i}+0,6 S D i<\bar{M} \leq M_{i}+1,8 S D i$ & Baik \\
$M_{i}-0,6 S D i<\bar{M} \leq M_{i}+0,6 S D i$ & Cukup \\
$M_{i}-1,8 S D i<\bar{M} \leq M_{i}-0,6 S D i$ & Kurang \\
$\bar{M} \leq M_{i}-1,8 S D i$ & Sangat \\
& Kurang \\
\hline
\end{tabular}

Berdasarkan rumus konversi pada Tabel 5 tersebut, diperoleh interval untuk masing- 
masing kategori. Dalam hal mengkonversi skorskor penilaian dari data kuantitatif ke data kualitatif bertujuan untuk menentukan kevalidan dan kepraktisan perangkat pembelajaran yang dihasilkan.

\section{HASIL DAN PEMBAHASAN}

Pengembangan dalam penelitian ini yaitu pengembangan perangkat pembelajaran yang meliputi silabus, Rencana Pelaksanaan Pembelajaran (RPP), Lembar Kegiatan Siswa (LKS), dan Tes Hasil Belajar (THB). Hasil pengembangan dari setiap tahapan adalah sebagai berikut.

\section{Tahap Pendefinisian}

Pada tahap ini dilakukan analisis awalakhir. Angket awal penelitian digunakan untuk memperoleh data pendukung mengenai permasalahan nyata di lapangan yang berkaitan dengan perangkat pembelajaran yang digunakan guru dalam proses pembelajarannya dan materi yang dirasakan sulit oleh siswa. Hasil angket awal terhadap guru menunjukkan bahwa dari 12 guru hanya terdapat dua guru yang mengembangkan silabus dan RPP. Guru yang melakukan penyusunan LKS secara mandiri hanya 2 guru. Sedangkan untuk analisis siswa diperoleh hasil angket terbuka yang diberikan kepada 28 siswa menunjukkan bahwa turunan fungsi merupakan mata pelajaran dianggap paling sulit oleh siswa. Yang menduduki tingkat kesulitan ke dua adalah limit fungsi.

Pada analisis tugas diperoleh bahwa pelaksanaan dan metode pembelajaran yang digunakan guru dalam pembelajaran masih berpusat pada guru. Metode pembelajaran yang sering digunakan adalah metode ceramah. Hanya satu guru yang menggunakan metode penemuan.

Untuk selanjutnya dilakukan Analisis konsep. Konsep dasar atau pedoman dalam pengembangan perangkat pembelajaran ini yaitu didasarkan pada aturan pengembangan perangkat dari Departemen Pendidikan Nasional. Hasil survey awal menunjukkan bahwa beberapa guru belum melakukan pengembangan berdasarkan aturan tersebut. Hal ini terlihat dari pengembangan perangkat pembelajaran secara mandiri hanya dilakukan oleh dua guru saja, sedangkan guru yang lain lebih banyak dengan mencontoh perangkat pembelajaran yang sudah ada yang belum sesuai dengan aturan yang berlaku.

Langkah terakhir dalam tahap pendefinisian ini adalah menentukan spesifikasi tujuan instruksiona. Dengan adanya beberapa permasa- lahan tersebut maka dapat disimpulkan bahwa permasalahan yang terjadi di lapangan yaitu perangkat pembelajaran yang digunakan belum merupakan hasil pengembangan guru secara mandiri. Jika dilihat dari metode pembelajaran yang digunakan, metode pembelajaran masih berpusat pada guru. Jika ditinjau dari materi yang menurut siswa mempunyai tingkat kesulitan paling tinggi adalah turunan fungsi, dan pada urutan kedua adalah limit fungsi.

\section{Tahap Perancangan}

Tahap ini bertujuan untuk merancang prototype perangkat pembelajaran matematika. Hasil yang diperoleh pada tahap perancangan adalah Silabus, RPP, LKS, dan THB, yang disebut draft-1. Perangkat pembelajaran yang dihasilkan terdiri dari Silabus, Rencana Pelaksanaan Pembelajaran, Lembar Kegiatan Siswa, dan Tes Hasil Belajar

\section{Tahap Pengembangan}

Setelah Draf 1 (Silabus, RPP, LKS, dan THB) terbentuk, dilanjutkan pada tahap pengembangan yaitu penyempurnaan Draf 1 . Langkah-langkah yang dilakukan adalah penilaian (validasi) ahli untuk Draf 1 oleh ahli pendidikan matematika. Revisi Draf 1 menghasilkan Draf II, kemudian dilakukan ujicoba terbatas Draf II. Analisis hasil ujicoba terbatas Draf II kemudian direvisi yang menghasilkan Draf III perangkat pembelajaran yang baik. Adapun hasil dari masing-masing langkahnya adalah sebagai berikut.

\section{Validasi Ahli}

Kegiatan validasi dilakukan dengan cara memberikan naskah produk draf 1 yaitu berupa silabus, RPP, LKS, dan THB serta lembar validasi kepada tiga validator ahli dan tiga praktisi. Sebagai validator dalam penelitian ini yaitu dosen dan guru pengampu mata pelajaran matematika. Data skor validasi produk awal pengembangan dari keenam validator untuk masingmasing komponen perangkat berturut-turut adalah: Silabus (879), RPP (1244), LKS (563), dan THB (439). Berdasarkan kriteria kevalidan komponen perangkat pembelajaran yang telah ditetapkan dapat diketahui tingkat kevalidan masing-masing komponen perangkat pembelajaran tersebut berada pada kategori sangat valid. Data hasil analisis kevalidan perangkat pembelajaran dapat dilihat pada tabel berikut. 
Tabel 5. Hasil Analisis Kevalidan Perangkat Pembelajaran

\begin{tabular}{|c|c|c|c|c|}
\hline No. & $\begin{array}{l}\text { Komponen } \\
\text { Perangkat }\end{array}$ & $\begin{array}{c}\text { Total } \\
\text { Skor } \\
\text { Validasi }\end{array}$ & $\begin{array}{l}\text { Rata- } \\
\text { rata } \\
\text { Skor }\end{array}$ & Kategori \\
\hline 1. & Silabus & 879 & 146,5 & $\begin{array}{l}\text { Sangat } \\
\text { Valid }\end{array}$ \\
\hline 2. & RPP & 1244 & 207,3 & $\begin{array}{l}\text { Sangat } \\
\text { Valid }\end{array}$ \\
\hline 3. & LKS & 563 & 93,83 & $\begin{array}{l}\text { Sangat } \\
\text { Valid }\end{array}$ \\
\hline 4. & THB & 439 & 73,17 & $\begin{array}{l}\text { Sangat } \\
\text { Valid }\end{array}$ \\
\hline
\end{tabular}

Penilaian pada uji coba terbatas meliputi penilaian siswa dan guru. Setelah dilaksanakan uji coba terbatas, siswa dan guru diminta melakukan penilaian. Dari data yang diperoleh kemudian dilakukan analisis data. Hasil penilaian siswa menunjukkan bahwa rata-rata persentase penilaian siswa yang memilih minimal baik untuk tiap aspek adalah $81,4 \%>80 \%$. Hal ini menunjukkan bahwa produk dalam kategori baik sehingga dapat disimpulkan produk layak digunakan pada uji coba lapangan. Penilaian guru juga semua aspek dalam kategori minimal baik. Hal ini berarti bahwa produk yang dikembangkan praktis untuk digunakan dalam pembelajaran karena dari setiap aspek yang dinilai dalam kategori minimal baik.

Tahap uji coba lapangan dilakukan untuk memperoleh data hasil observasi keterlaksanaan pembelajaran, data penilaian siswa, data penilaian guru dan data tes hasil belajar. Data-data tersebut selanjutnya digunakan untuk mengetahui kepraktisan (practicality) dan keefektifan (effectiveness) perangkat pembelajaran kalkulus SMA yang dikembangkan. Pengambilan data ini dilaksanakan dalam proses pembelajaran selama 10 (sepuluh) pertemuan. Alokasi waktu dalam setiap pertemuan adalah $2 \times 45$ menit atau dua jam pelajaran.

Kepraktisan perangkat didasarkan pada haasil observasi kegiatan guru dan siswa dan hasil penilaian guru dan siswa. Berdasarkan data hasil observasi kegiatan guru dan siswa yang dilakukan oleh dua orang observer selama 10 (sepuluh) kali pertemuan, diketahui bahwa observasi kegiatan siswa pada tujuh pertemuan berkategori sangat baik, yaitu pertemuan 4-10, sedangkan pertemuan 1-3 berkategori baik, sedangkan observasi kegiatan guru pada pertemuan 1-9 berkategori baik dan pada pertemuan 10 berkategori sangat baik.

Kepraktisan juga didasarkan dari hasil penilaian guru. Dari data skor penilaian guru setelah melaksanakan proses pembelajaran dengan produk perangkat hasil pengembangan, diketahui bahwa semua produk (silabus, RPP, LKS, THB ) memenuhi kategori baik.

Disamping penilaian guru, kepraktisan juga didasarkan pada penilaian siswa. Penilaian siswa ini meliputi pelaksanaan pembelajaran dan LKS yang digunakan. Berdasarkan data skor penilaian diketahui bahwa total skor yang diperoleh dengan kategori minimal baik untuk pelaksanaan pembelajaran adalah $84,4 \%>80 \%$ dan LKS adalah $84,4 \%>80 \%$. Hal ini menunjukkan bahwa perangkat pembelajaran kalkulus SMA yang dihasilkan memenuhi kriteria praktis.

Berdasarkan hasil analisis data observasi keterlaksanaan pembelajaran, penilaian guru dan penilaian siswa, dapat disimpulkan terdapat konsistensi penilaian yang baik/positif dari guru dan siswa serta tingkat keterlaksanaan pembelajaran yang sangat tinggi di lapangan. Hal ini menunjukkan bahwa perangkat pembelajaran kalkulus SMA yang dihasilkan memenuhi kriteria praktis untuk digunakan.

Analisis data keefektifan didasarkan pada data tes ulangan harian Ketuntasan siswa belajar dari 56 siswa yang mengikuti tes adalah $82,14 \%$ $>80 \%$ atau sebanyak 46 siswa. Sedangkan reliabilitas hasil tes adalah 0,72 . Karena kelulusan lebih dari $80 \%$ dan tingkat reliabilitasnya reliabel maka disimpulkan bahwa produk efektif untuk digunakan dengan tingkat keefektifan sangat efektif.

Berdasarkan hasil uji coba pada tahap sebelumnya, selanjutnya dilakukan revisi-revisi terhadap perangkat pembelajaran kalkulus SMA yang dihasilkan. Revisi dilakukan sebanyak 3 (tiga) kali berdasarkan hasil dari masing-masing uji coba. Revisi I dilakukan berdasarkan hasil uji coba ahli/validasi ahli (expert judgement). Revisi II dilakukan berdasarkan hasil uji coba terbatas/ kelompok kecil (small group try-out). Yang terakhir, revisi III dilakukan berdasarkan hasil uji coba lapangan. Hasil revisi III selanjutnya digunakan sebagai dasar menyusun produk akhir pengembangan.

Revisi I dilakukan berdasarkan saran/ masukan validator dari hasil uji coba ahli. Revisi atau perbaikan dilakukan terhadap produk pengembangan berupa perangkat pembelajaran kalkulus SMA yang telah dihasilkan, meliputi silabus, rencana pelaksanaan pembelajaran (RPP), lembar kegiatan siswa (LKS), dan tes hasil belajar (THB). Secara ringkas saran/ masukan validator yang dijadikan sebagai dasar revisi I disajikan dalam tabel berikut. 
Tabel 6. Saran/Masukan hasil Uji Coba Ahli

\begin{tabular}{ll}
\hline Komponen & \multicolumn{1}{c}{ Saran/Masukan } \\
\hline Silabus & $\begin{array}{l}\text { Pembenahan penulisan limit fungsi } \\
\text { pada contoh instrument }\end{array}$ \\
RPP & $\begin{array}{l}\text { Perlu perbaikan gambar/grafik, } \\
\text { penyesuaian satuan waktu, penilaian }\end{array}$ \\
& kuis, font huruf, materi ajar \\
LKS & $\begin{array}{l}\text { Perlu perbaikan pada beberapa } \\
\text { gambar, tabel, petunjuk pengerjaan, }\end{array}$ \\
& $\begin{array}{l}\text { penulisan limit } \\
\text { THB }\end{array}$ \\
& $\begin{array}{l}\text { Perlu perbaikan pada redaksional } \\
\text { beberapa soal dan beberapa gambar, } \\
\text { penyesuaian penskoran, pembetulan } \\
\text { penulisan }\end{array}$ \\
\hline
\end{tabular}

Revisi II dilakukan berdasarkan hasil uji coba terbatas. Kegiatan ini dilakukan dengan cara meminta siswa untuk menilai dan memberikan masukan atas produk pengembangan yang berupa lembar kegiatan siswa (LKS). Berdasarkan hasil dari kegiatan ini dilakukan revisi atau perbaikan produk pengembangan berupa LKS sebagai komponen pendukung perangkat pembelajaran kalkulus SMA yang telah dihasilkan. Beberapa revisi yang dilakukan pada tahap ini adalah mengubah beberapa soal ,kata/istilah, petunjuk dan bahasa,

Revisi III dilakukan berdasarkan saran/ masukan guru dan hasil pengamatan di lapangan dalam uji coba lapangan. Secara ringkas beberapa revisi tersebut disajikan pada tabel di bawah.

Tabel 7. Revisi Hasil Uji Coba Lapangan

\begin{tabular}{ll}
\hline Komponen & \multicolumn{1}{c}{ Bagian yang direvisi } \\
\hline Silabus & $\begin{array}{l}\text { Menambahkan Contoh instrumen } \\
\text { tidak hanya terdiri dari satu soal. } \\
\text { Rengubah kata fasilitas dan motivasi } \\
\text { menjadi bimbingan }\end{array}$ \\
\hline
\end{tabular}

\section{Kajian Produk Akhir}

Kajian tentang perangkat pembelajaran hasil pengembangan dalam penelitian pengembangan perangkat pembelajaran matematika pada materi pokok kalkulus menggunakan pendekatan pembelajaran kooperatif tipe STAD dan TAI siswa SMA, dapat disajikan dalam pembahasan berikut.

Kevalidan

Pada tahap validasi ditemukan bahwa perangkat pembelajaran matematika pada materi pokok kalkulus menggunakan pendekatan pembelajaran kooperatif tipe STAD dan TAI siswa SMA, sudah memenuhi kelayakan untuk digunakan. Kelayakan tersebut dilihat dari rata- rata skor validitas silabus yaitu 146,5 dengan kategori "sangat valid". Rata-rata skor validitas RPP yaitu 207,3 dengan kategori "sangat valid". Rata-rata skor validitas LKS yaitu 93,83 dengan kategori "sangat valid". Hasil validitas tes hasil belajar yaitu 73,17 dengan kategori "sangat valid". Sesuai dengan kualitas produk yang telah ditetapkan pada Bab III bahwa produk yang dikembangkan dianggap layak digunakan apabila aspek-aspek yang dinilai pada perangkat pembelajaran seperti silabus, RPP, LKS, dan THB mencapai kategori minimal "valid."

\section{Kepraktisan}

Untuk mengukur kepraktisan produk dilakukan dengan melihat hasil observasi dan hasil penilaian guru dan siswa pada saat uji coba lapangan. Observasi kegiatan siswa menunjukkan bahwa kegiatan siswa dalam pembelajaran berkategori minimal baik, bahkan tujuh pertemuan terakhir kegiatan siswa berkategori sangat baik. Hasil observasi kegiatan guru menunjukkan bahwa kegiatan guru dalam pembelajaran berkategori minimal baik, dan pada pertemuan terakhir kegiatan guru berkategori sangat baik.

Hasil penilaian guru menunjukkan bahwa produk yang digunakan dalam pembelajaran berkategori minimal baik. Hasil penilaian siswa menunjukkan bahwa persentase siswa yang memilih pelaksanaan pembelajaran dan LKS yang digunakan minimal baik sebanyak $84,4 \%$.

\section{Keefektifan}

Untuk mengukur keefektifan produk dilakukan dengan melihat hasil tes hasil belajar siswa pada saat uji coba lapangan. Hasil tes hasil belajar siswa menunjukkan bahwa siswa yang tuntas sebanyak $82,14 \%$ dan soal yang digunakan telah reliabel karena nilai reliabilitasnya sebesar 0,72. Karena jumlah ketuntasan siswa lebih dari $80 \%$, maka disimpulkan bahwa produk yang terdiri dari silabus, RPP, LKS, dan THB efektif dengan tingkat keefektifan sangat baik

\section{SIMPULAN DAN SARAN}

\section{Simpulan}

Produk yang dikembangkan berupa perangkat pembelajaran matematika menggunakan metode pembelajaran kooperatif pada materi pokok kalkulus SMA kelas XI yang meliputi silabus, Rencana Pelaksanaan Pembelajaran (RPP), Lembar Kegiatan Siswa (LKS) dan Tes Hasil Belajar (THB) yang baik dan layak untuk digunakan. Dan perangkat pembelajaran perang- 
kat pembelajaran matematika menggunakan metode pembelajaran kooperatif pada materi pokok kalkulus SMA kelas XI yang meliputi silabus, Rencana Pelaksanaan Pembelajaran (RPP), Lembar Kegiatan Siswa (LKS) dan Tes Hasil Belajar (THB) termasuk ke dalam kategori sangat valid, praktis, dan efektif.

\section{Saran}

Adapun saran pemanfaatan produk yang dikembangkan ini dapat dijadikan sebagai contoh pembelajaran matematika yang menggunakan metode pembelajaran kooperatif tipe STAD dan TAI. Dapat juga dijadikan contoh pembelajaran yang berpusat pada siswa sehingga siswa dapat berperan aktif dalam pembelajaran.

\section{DAFTAR PUSTAKA}

Anderson, L.M. (2001). Nine prospective teachers and their experiences in teacher education: the role of entering conceptions of teaching and learning. Dalam Torff, B. \& Sternberg, R.J. (Eds.), Understanding and Teaching the Intuitive Mind: Student and Teacher Learning (pp. 187-215). London: Lawrence Erlbaum Associates.

BNSP. (2006a). Panduan penyusunan kurikulum tingkat satuan pendidikan jenjang pendidikan dasar dan menengah. Jakarta: BSNP

BNSP. (2007). Peraturan Menteri Pendidikan Nomor 41 Tahun 2007 tentang Standar Proses. Jakarta: Depdiknas

Borich, G.D. (2000). Effective teaching methods $\left(4^{\text {th }}\right.$ ed). Upper Saddle River, NJ: Prentice Hall.

Depdiknas. (2008e). Teknis penyusunan RPP pada sekolah menengah kejuruan. Jakarta: Direktorat Pembinaan Sekolah Menengah Kejuruan.

Depdiknas. ((2010). Juknis penyusunan perangkat penilaian afektif. Jakarta: Direktorat Pembinaan Sekolah Menengah Atas

Erman Suherman, dkk. (2003). Strategi pembelajaran matematika kontemporer. Bandung: Universitas Pendidikan Indonesia.
Harjanto. (2003). Perencanaan Pengajaran Jakarta: PT Rineka Cipta.

Kennedy, M.L., Tipps, S,. \& Johnson, A. (2008). Guiding children's learning of mathematics. New York, NY: Thomson Higher Education.

Nieveen, N. (1999). Prototyping to reach product quality. London: Kluwer Academic Publisher. Dalam Akker, J., Branch, R.M., Gustafson, K., et al. (Eds.), Design Approaches and Tools in Education and Training (pp. 126-135). Dordrecht: Kluwer Academic Publishers.

O'Brien, J.G., Millis, B.J, \& Cohen, M.W. (2008). The course syllabus a learning centered approach. San Fransisco, CA: Josey Bass.

Partin, R. (2009). The classroom teacher's survival guide $\left(3^{\text {th }} \mathrm{ed}\right)$. San Fransisco, CA: John Wiley \& Sons.

Peraturan Pemerintah RI Nomor 19 Tahun 2005 Tentang Standar Nasional. Diambil pada tanggal 12 November 2012, dari http://www.presidenri.go.id/ DokumenUU.php/104.pdf

Prescott, A. (2011). Are we singing from the same songbook? Dalam Sandy Schuck, S. \& Pereira, P. (Eds.), What Counts in Teaching Mathematics, (pp. 161-176). New York, NY: Springer

Slavin. (1995). Cooperative learning ( $2^{\text {nd }}$ ed.). Boston, MA: Allyn and Bacon.

Steinbring, H. (2005). The construction of new mathematical knowledge in classroom interaction: an epistemological perspective. New York, NY: Springer Science+Business Media.

Thiagarajan S., Semmel D., \& Semmel, M.I. (1974). Intructional development for training teachers of exceptional children: A sourcebook. Minnesota: Central for Innovation on Teaching the Handicaped..

Trianto. (2009). Mendesain model pembelajaran inovatif-progresif: konsep, landasan, dan implementasinya pada kurikulum tingkat satuan pendidikan (KTSP). Jakarta: Kencana. 